Article

\title{
Size-Controlled Production of Gold Bionanoparticles Using the Extremely Acidophilic Fe(III)-Reducing Bacterium, Acidocella aromatica
}

\author{
Intan Nurul Rizki and Naoko Okibe * \\ Department of Earth Resources Engineering, Faculty of Engineering, Kyushu University, 744 Motooka, Nishi-ku, \\ Fukuoka 819-0395, Japan; intan@mine.kyushu-u.ac.jp \\ * Correspondence: okibe@mine.kyushu-u.ac.jp; Tel.: +81-92-802-3312
}

Received: 24 January 2018; Accepted: 22 February 2018; Published: 26 February 2018

\begin{abstract}
Recycling of gold-bearing "urban mine" resources, such as waste printed circuit boards (PCBs), is attracting an increasing interest. Some of the gold leaching techniques utilize acidic lixiviants and in order to eventually target such acidic leachates, the utility of the acidophilic Fe(III)-reducing heterotrophic bacterium, Acidocella (Ac.) aromatica PFBC was evaluated for production of $\mathrm{Au}(0)$ bionanoparticles (bio-AuNPs). $\mathrm{Au}(\mathrm{III})$ ions (as $\mathrm{AuCl}_{4}{ }^{-}$, initially $10 \mathrm{mg} / \mathrm{L}$ ), were readily adsorbed onto the slightly-positively charged Ac. aromatica cell surface and transported into cytoplasm to successfully form intracellular bio-AuNPs in a simple one-step microbiological reaction. Generally, increasing the initial concentration of formate as e-donor corresponded to faster $\mathrm{Au}(\mathrm{III})$ bioreduction and a greater number of $\mathrm{Au}(0)$ nucleation sites with less crystal growth within 40-60 h: i.e., use of 1,5, 10 , or $20 \mathrm{mM}$ formate led to production of bio-AuNPs of 48,24,13, or $12 \mathrm{~nm}$ in mean particle size with $2.3,17,62$, and 97 particles/cell, respectively. Addition of $\mathrm{Cu}^{2+}$ as an enzymatic inhibitor significantly decreased the number of $\mathrm{Au}(0)$ nucleation sites but enhanced crystal growth of individual particles. As a result, the manipulation of the e-donor concentration combined with an enzyme inhibitor enabled the 3-grade size-control of bio-AuNPs (nearly within a normal distribution) at 48, 26 or $13 \mathrm{~nm}$ by use of $1 \mathrm{mM}$ formate, $20 \mathrm{mM}$ formate $\left(+\mathrm{Cu}^{2+}\right)$ or $10 \mathrm{mM}$ formate, respectively, from highly acidic, dilute $\mathrm{Au}(\mathrm{III})$ solutions.
\end{abstract}

Keywords: gold nanoparticles; Acidocella aromatica PFBC; Fe(III)-reducing bacterium; acidophilic microorganism; size-control

\section{Introduction}

Industrial demands for precious-group metals (PGMs), together with the growing needs for cost effectiveness and implementation of green technology are increasing rapidly. Due to the rarity of the metals and their uneven distribution, the importance to recycle PGMs from secondary resources is inevitable. As one of the PGMs, Au is recognized as one of the most expensive metals historically in the world [1].

Today, industrial demands prefer Au mostly in the form of nanoparticles, rather than in bulk metal, owing to a variety of their unique properties. Nanoparticles tend to be more reactive due to their greater specific surface area than larger particles. $\mathrm{Au}(0)$ nanoparticles (AuNPs) have thus been applied to many different applications across the field of biology and medicine (e.g., labeling, bio-imaging, drug delivery [2,3]), environment (e.g., pollution control and water purification [4], catalysts for green chemistry [5,6], nanobiosensors in food and agriculture industry [7,8]), and technology (e.g., improving computer memory [9]).

A number of chemical synthesis methods have been so far reported for the production of AuNPs [10]. One of the most frequently used approaches is the in-situ chemical reduction method, 
which consists of two major steps (i.e., the first chemical reduction step using agents, such as borohydrides, and the second stabilization step using agents, such as trisodium citrate dehydrate) [10].

For "greener" syntheses of AuNPs as compared to the conventional approaches, the usefulness of biological methods has recently been increasingly recognized. In these methods, a variety of biomaterials (such as plants, natural source extracts, chitosan, and microbial cells) directly act as both reducing agent and stabilizer to form AuNPs [10-13].

Among such biomaterials, bacterial cells are generally easily replicated and maintained, making them one of the most ideal low-cost materials for metal nanoparticles production. Since interactions between bacterial cells and different metals have been well documented [14], such natural geomicrobiological reactions have a great potential to be utilized in the production of diverse metal nanoparticles.

So far, studies on bacterial bio-AuNPs reported formations of a diverse size range of particles in different cellular locations (extra- and intracellular regions, including cell surface, periplasmic space and cytoplasms). These studies used either Au(I)-thiosulfate or Au(III)-chloride as a starting Au solution with or without e-donor, by employing extensively neutrophilic bacteria (even under acidic experimental pHs): i.e., different Bacillus spp. (a few nano- to micro-size, extra- and intracellular [15-20]); Lactobacillus spp. (5-30 nm, intracellular [21]; 20-50 nm and >100 nm, extra- and intracellular [22]); Pseudomonas aeruginosa (15-30 nm, extracellular [23]); Escherichia coli and Desulfovibrio desulfuricans (20-50 nm, intracellular; [24]); a range of dissimilatory Fe(III)-reducing bacteria/archaea including Pyrobaculum islandicum, Pyrococcus furiosus, Thermotoga maritima, Shewanella algae, Geobacter sulfurreducens and Geovibrio ferrireducens (nano-size, intracellular [25,26]); Rhodopseudomonas capsulate (10-20 nm, extracellular [27]); Rhodobacter capsulatus (<50 nm, extra- and intracellular [28]), Stenotrophomonas maltophilia (40 nm, intracellular [29]), Ralstonia metallidurans (extra- and intracellular [30]), sulfate-reducing bacteria (mostly $<10 \mathrm{~nm}$, extra- and intracellular [31]), and the radiation-resistant Deinococcus radiodurans (44 nm, extra- and intracellular [32]).

Since some of the gold leaching techniques utilize acidic lixiviants, such as chloride solution and thiourea, plus ferric iron solution, investigating the potential of extremely acidophilic bacteria for bio-AuNPs production is important. However, to our knowledge, the only acidophilic extremophile so far tested for bio-AuNPs production is the autotrophic S-oxidizer, Acidithiobacillus (At) thiooxidans. The bacterium deposited fine-grained $\mathrm{Au}(0)$ colloids $(5-10 \mathrm{~nm})$, by utilizing $\mathrm{Au}\left(\mathrm{S}_{2} \mathrm{O}_{3}\right)_{2}{ }^{3-}$ as an energy source, throughout the cell, especially along the cytoplasmic membrane [33].

In both neutrophilic and acidophilic bacterial AuNPs studies, as described above, attempts to control the particle size have been hardly reported.

Hence, the objective of this study was set to investigate the utility of the acidophilic Fe(III)-reducing heterotrophic bacterium, Acidocella aromatica PFBC, for the production of bio-AuNPs from acidic, dilute $\mathrm{Au}(\mathrm{III})$ solutions, especially with the aim to recover them with size-control.

\section{Materials and Methods}

\subsection{Microorganism}

Acidocella aromatica $\mathrm{PFBC}^{\mathrm{T}}$ (DSM 27026; [34]) was routinely maintained and pre-grown aerobically in $500 \mathrm{~mL}$ Erlenmeyer flasks containing $200 \mathrm{~mL}$ heterotrophic basal salts (HBS) medium (pH 2.5 with $\mathrm{H}_{2} \mathrm{SO}_{4}$; per liter; $50 \mathrm{mg} \mathrm{KCl}, 500 \mathrm{mg} \mathrm{MgSO} \cdot 7 \mathrm{H}_{2} \mathrm{O}, 50 \mathrm{mg} \mathrm{KH} \mathrm{PO}_{4}, 450 \mathrm{mg}\left(\mathrm{NH}_{4}\right)_{2} \mathrm{SO}_{4}, 142 \mathrm{mg} \mathrm{Na}_{2} \mathrm{SO}_{4}$ ， $\left.14 \mathrm{mg} \mathrm{Ca}\left(\mathrm{NO}_{3}\right)_{2} \cdot 4 \mathrm{H}_{2} \mathrm{O}\right)$ containing $10 \mathrm{mM}$ fructose and $0.025 \%(v / v)$ tryptone soya broth (TSB). Flasks were incubated at $30^{\circ} \mathrm{C}$, and shaken at $100 \mathrm{rpm}$.

\subsection{Bioreduction of $A u(I I I)$ by Ac. aromatica Cell-Suspensions}

Ac. aromatica was pre-grown aerobically, harvested at the late-exponential phase by centrifugation, washed twice, and finally re-suspended (to a final cell density of $10^{9}$ cells $/ \mathrm{mL}$ ) in $25 \mathrm{~mL}$ of fresh HBS medium ( $\mathrm{pH} 2.5$; in $25 \mathrm{~mL}$ vials) containing $10 \mathrm{mg} / \mathrm{L} \mathrm{Au}(\mathrm{III})$ (as $\mathrm{HAuCl}_{4} \cdot 3 \mathrm{H}_{2} \mathrm{O}$ ). After incubating vials 
for $1 \mathrm{~h}$ to allow Au(III) biosorption, sodium formate (HCOONa) was added as e-donor at 1, 5, 10, and $20 \mathrm{mM}$. It should be noted that sodium formate $\left(\mathrm{pK}_{\mathrm{a}}=3.75\right)$ added to the media hereafter was likely present predominantly as formic acid under the acidic conditions used.

Where indicated, $\mathrm{Cu}^{2+}\left(\right.$ as $\left.\mathrm{CuSO}_{4} \cdot 7 \mathrm{H}_{2} \mathrm{O}\right)$ was added to the medium at the initial concentration of $5 \mathrm{mM}$ as a potential enzyme inhibitor at $1 \mathrm{~h}$. Cell-free controls were also set up in parallel.

After cells were pre-grown aerobically, all of the solutions used were prepared anaerobically by $\mathrm{N}_{2}$-purging $(6 \mathrm{~h} / \mathrm{L}$-medium). Vials were sealed with butyl-rubber stoppers and aluminum crimps, and were incubated unshaken at $30{ }^{\circ} \mathrm{C}$ (in contrast, aerobic incubation did not reduce gold; data not shown).

Samples were regularly withdrawn and filtered $(0.2 \mu \mathrm{m})$ to measure the total soluble $\mathrm{Au}$ concentration by ICP-OES (Perkin Elmer Optima 8300, Waltham, MA, USA). Following the completion of $\mathrm{Au}$ (III) reduction (using $20 \mathrm{mM}$ formate), cells were harvested at $160 \mathrm{~h}$ for XRD analysis (Rigaku UltimaIV; CuK $\alpha 40 \mathrm{~mA}, 40 \mathrm{kV}$, Tokyo, Japan). All of the experiments were conducted in duplicate.

\subsection{Zeta-Potential Measurement}

Ac. aromatica cells were harvested, washed twice, and re-suspended in $10 \mathrm{~mL}$ of $10 \mathrm{mM} \mathrm{NaCl}$ solution ( $\mathrm{pH} 2.5$ with $\mathrm{HCl}$ or $\mathrm{NaOH}$ ) to a final cell density of $10^{8}$ cells $/ \mathrm{mL}$. After the addition of $\mathrm{Au}$ (III) at $10 \mathrm{mg} / \mathrm{L}$, cells were left for $30 \mathrm{~min}$ prior to the zeta-potential measurement (Malvern ZETASIZER Nano series, Malvern Co., Ltd., Malvern, UK). The measurement was conducted in duplicate.

\subsection{Ultra-Thin Section Transmission Electron Microscopy (TEM) Observation}

TEM ultra-thin section was performed to observe the distribution and localization of the resultant bio-AuNPs. Cells were collected at $160 \mathrm{~h}$ after exposure to Au(III) by centrifugation (12,000 rpm for $10 \mathrm{~min}$ ), followed by a two-step cell fixation (by using mixture of $4 \%$ paraformaldehyde plus $2.5 \%$ glutaraldehyde, followed by $1 \%$ osmium tetroxide). Cells were dehydrated using an ethanol series $(70 \%, 80 \%, 90 \%$ and $99.5 \%$ ethanol for 5 min each step, and finally 100\% dried ethanol for $10 \mathrm{~min}$ ), washed with propylene oxide and finally polymerized with resin (contained Epon 812, DDSA, NMA, and DMP-30). The polymerized samples were cut into $70 \mathrm{~nm}$ thickness with a diamond knife (SUMI knife) using ultramicrotome (Leica EM UC7). The ultra-thin film was located on the copper micro grid and stained with ESTM and Pb-citrate for $10 \mathrm{~min}$, respectively, prior to TEM observation (FEI TECNAI-20, Hillsboro, OR, USA). TEM images were used to calculate the average density of bio-AuNPs (particles/cell) under each condition.

\subsection{Particle Size Analysis Using Image-J}

Image-J software (National Institute of Health, Rockville, MD, USA) was used to analyze the particle size of bio-AuNPs. A total of over 70 nanoparticles were analyzed to calculate the diameter and its standard deviation (except that only 25 and 17 particles were available at 0 and $5 \mathrm{mM}$ formate, respectively). Firstly, the images were calibrated and thresholded by selecting the ROI (region of interest) and removing the background noise. The particles were then analyzed with the "Analyze Particle" function, which calculates the projected area of an individual particle. Assuming that the particle is spherical, the diameter of each particle was calculated from its projected area.

\section{Results and Discussion}

\section{1. $A u(I I I)$ Biosorption and Bioreduction}

About $8.5-9 \mathrm{mg} / \mathrm{L}$ of $\mathrm{Au}(\mathrm{III})$ ions were rapidly biosorped onto the Ac. aromatica cell surface within $10 \mathrm{~min}$, before adding formate as e-donor at $1 \mathrm{~h}$ (Figure 1). In fact, the zeta-potential measurement showed that a weakly positive surface charge exhibited by Ac. aromatica cells $(+2.5 \mathrm{mV}$ at $\mathrm{pH} 2.5)$ was shifted slightly negative $(+1.9 \mathrm{mV}$ at $\mathrm{pH} 2.5)$ after mixing with $\mathrm{Au}(\mathrm{III})$ (in the form of $\mathrm{Au}^{\mathrm{III}} \mathrm{Cl}_{4}{ }^{-}$) (Figure 2), implying the occurrence of $\mathrm{Au}(\mathrm{III})$ biosorption on the cell surface. On the other hand, 
no instant decrease in Au concentration was observed in cell-free controls (Figure 1a). Upon the addition of formate at $1 \mathrm{~h}$, the initial biosorption step was followed by an apparent induction phase before $\mathrm{Au}(\mathrm{III})$ bioreduction was started to produce $\mathrm{Au}(0)$ (Figure 1b). Higher formate concentrations led to less noticeable induction time and faster $\mathrm{Au}(\mathrm{III})$ bioreduction: At 1, 5, 10, and $20 \mathrm{mM}$ formate, $\mathrm{Au}(\mathrm{III})$ was completely reduced within 60, 60, 50, and 40 h, respectively (Figure 1b). Meanwhile, in cell-free controls, the Au concentration started to decrease only after $40 \mathrm{~h}$ due to its chemical reduction by $20 \mathrm{mM}$ formate (Figure 1a). Without formate addition, the biosorption step was followed by a slower and incomplete decrease in the $\mathrm{Au}$ concentration (Figure $1 \mathrm{~b}$ ). Addition of $5 \mathrm{mM} \mathrm{C \textrm {u } ^ { 2 + }}$ simultaneously with $20 \mathrm{mM}$ formate at $1 \mathrm{~h}$ did not show a significantly different trend in soluble Au concentrations, when compared to that without $\mathrm{Cu}^{2+}$ (Figure $1 \mathrm{~b}$ ).

As compared to the case with At. thiooxidans [33], it was possible to rapidly produce bio-AuNPs by using Ac. aromatica with addition of formate as e-donor. Also, the fact that biomass of acidophilic heterotrophs is generally more readily obtained compared to the autotrophs suggest the potential advantage of using acidophilic heterotrophs for bio-AuNPs from acidic solutions.

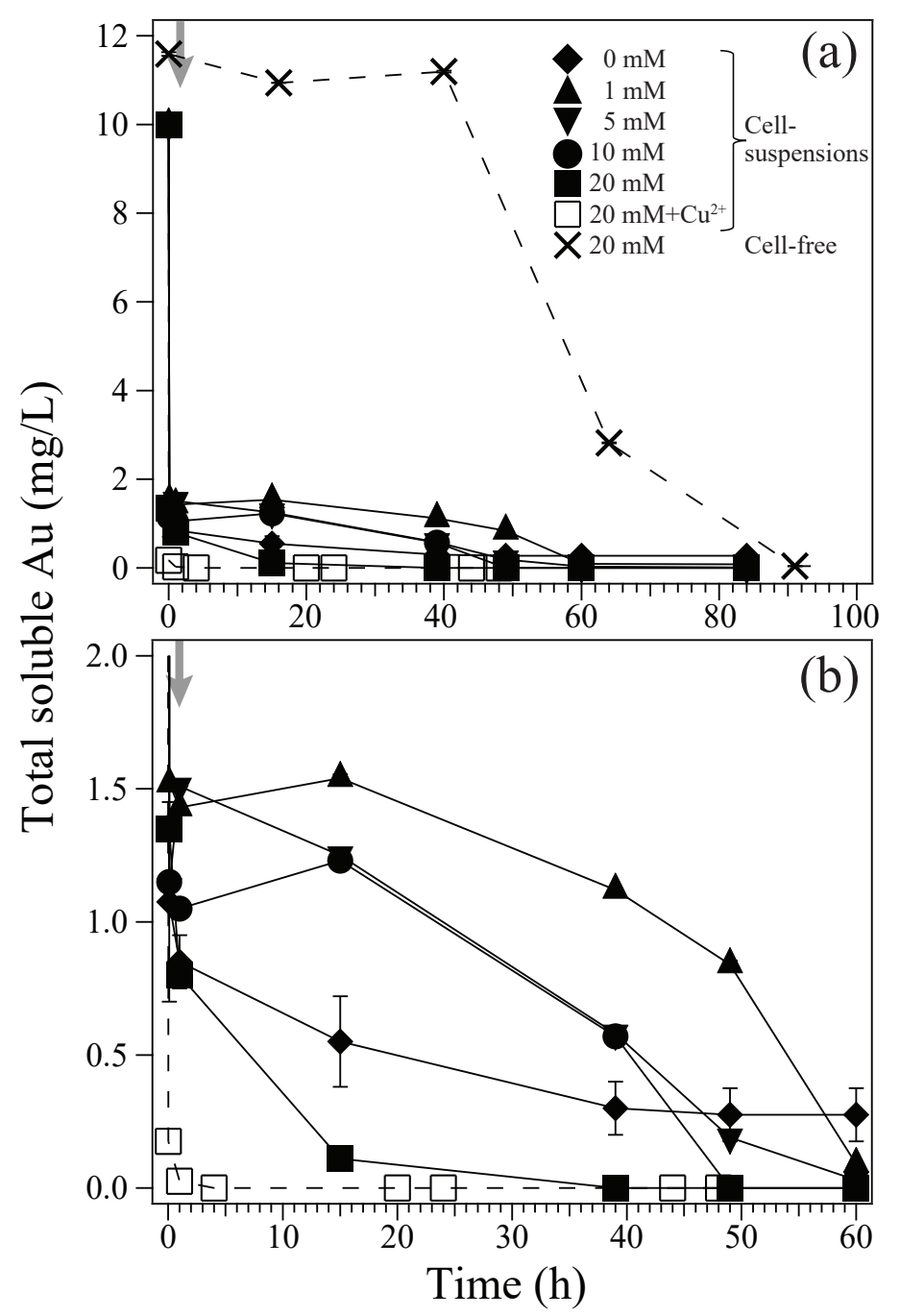

Figure 1. $\mathrm{Au}(\mathrm{III})$ biosorption and bioreduction in cell-suspensions of Ac. aromatica (pH 2.5). (a) Different initial concentrations of formate were used as e-donor; $\bullet \mathrm{mM}, \mathbf{\Delta} 1 \mathrm{mM}, \mathbf{\nabla} 5 \mathrm{mM}, \bullet 10 \mathrm{mM}$, and $20 \mathrm{mM}$ (solid lines). As a potential enzymatic inhibitor, $5 \mathrm{mM} \mathrm{Cu}^{2+}$ was added with $20 \mathrm{mM}$ formate ( $\square$; dotted line). Cell-free controls with $20 \mathrm{mM}$ formate ( $\times$; dotted line) were also tested. (b) shows the same data on an enlarged $x$ and $y$-axis. Grey arrows indicate the time of formate addition at $1 \mathrm{~h}$. 


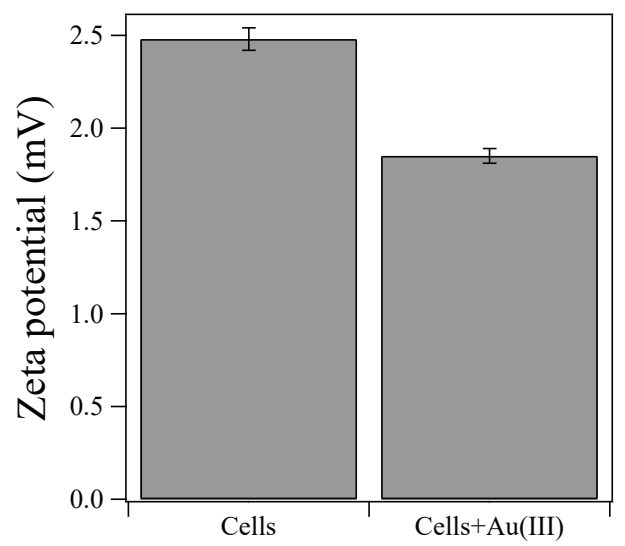

Figure 2. Zeta-potential measurement of Ac. aromatica cells at $\mathrm{pH} 2.5$, with or without mixing with $10 \mathrm{mg} / \mathrm{L} \mathrm{Au}(\mathrm{III})$.

\subsection{Size, Density and Localization of Bio-AuNPs}

\subsubsection{Size and Density}

After $\mathrm{Au}(\mathrm{III})$ reduction to produce bio-AuNPs, as confirmed by XRD analysis (Figure 3), Ac. aromatica cell-suspensions exhibited different intensity of pink color, in accordance with the initial formate concentration (Figure $4 \mathrm{~b}-\mathrm{f}$ ), except at $0 \mathrm{mM}$ formate where $\mathrm{Au}(\mathrm{III})$ bioreduction was incomplete and no clear color change was noticed (Figure 4a). TEM observation (Figure 5) combined with Image-J particle size analysis (Figure 6) revealed that $\mathrm{Au}(\mathrm{III})$ bioreduction at increasing formate concentrations $(1,5,10,20 \mathrm{mM})$ resulted in higher bio-AuNPs densities $(2.3,17,62$, and 97 particles/cell; Figure $5 \mathrm{~b}-\mathrm{e})$, with finer particle sizes $(48,24,13$, and $12 \mathrm{~nm}$; Figure $6 \mathrm{~b}-\mathrm{e})$, respectively. The addition of $\mathrm{Cu}^{2+}$, together with $20 \mathrm{mM}$ formate, led to the production of significantly fewer but larger particles (6.5 particles/cell and $26 \mathrm{~nm}$; Figures $5 \mathrm{f}$ and $6 \mathrm{f}$, respectively) as compared to the $\mathrm{Cu}^{2+}$-free counterpart (97 particles/cell and $12 \mathrm{~nm}$; Figures 5e and 6e, respectively). Slightly purple coloration in cell-free controls with $20 \mathrm{mM}$ formate (Figure 3g), together with a decrease in total Au concentration (Figure 1a), suggested the formation of relatively larger bio-AuNPs. However, it was not possible to harvest any precipitates from the solution by centrifugation. The above results indicate that the color transition from light-purple, pink, then to pink-red (Figure $4 \mathrm{~b}-\mathrm{f}$ ) was particle-size dependent (arranged roughly from larger to smaller particle size; Figure $6 \mathrm{~b}-\mathrm{f}$ ). Indeed, color change of several types of biomass after exposure to $\mathrm{Au}(\mathrm{III})$ ions was also reported in previous studies, e.g., [25-27,35]. Purple-pink coloration of colloidal Au is due to excitation of surface plasmon vibrations in the AuNPs [36]. Use of heat-killed Ac. aromatica cells instead of active cells generally resulted in the production of fewer and larger bio-AuNPs (data not shown). This indicated the importance of using active cells for bionanoparticles production, as was also the case in bio-PdNPs formation [13].

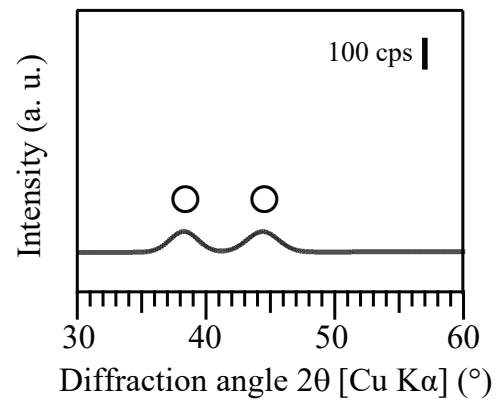

Figure 3. X-ray diffraction pattern of the resultant $\mathrm{Au}(0)$ bionanoparticles produced by Ac. aromatica using $20 \mathrm{mM}$ formate as e-donor. Open circles are assigned to metallic Au(0) (PDF No. 03-065-8601). 


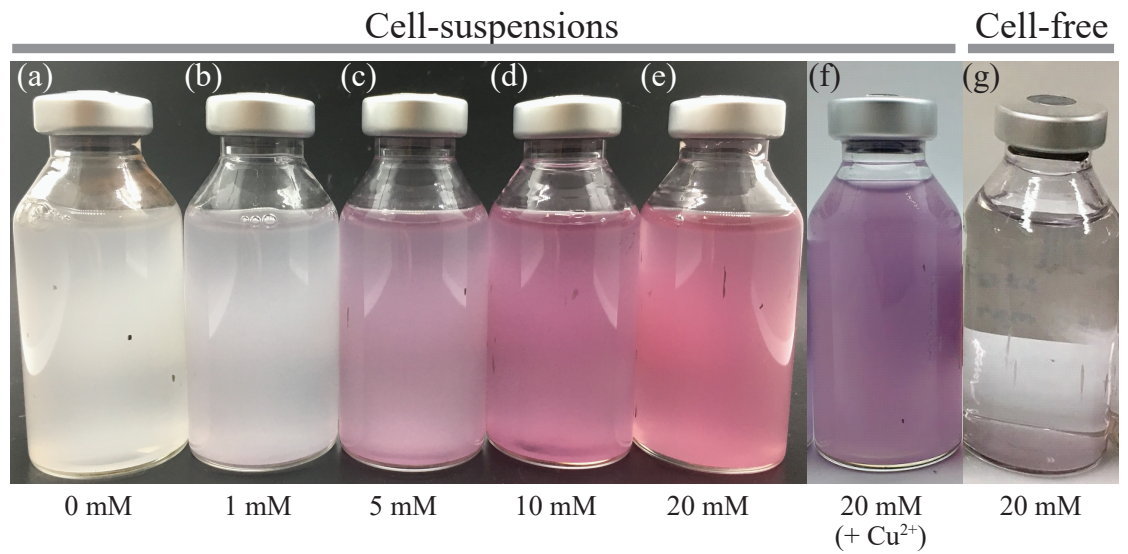

Figure 4. Color change of Ac. aromatica cell-suspensions after $\mathrm{Au}(\mathrm{III})$ reduction (at $160 \mathrm{~h}$ after exposure to $10 \mathrm{mg} / \mathrm{L} \mathrm{Au}(\mathrm{III})$ ). Formate was added as e-donor at; (a) $0 \mathrm{mM}$, (b) $1 \mathrm{mM}$, (c) $5 \mathrm{mM}$, (d) $10 \mathrm{mM}$, or (e) $20 \mathrm{mM}$. (f) As a possible enzymatic inhibitor, $5 \mathrm{mM} \mathrm{Cu}^{2+}$ was simultaneously added together with $20 \mathrm{mM}$ formate. (g) Cell-free controls were also tested at $20 \mathrm{mM}$ formate.

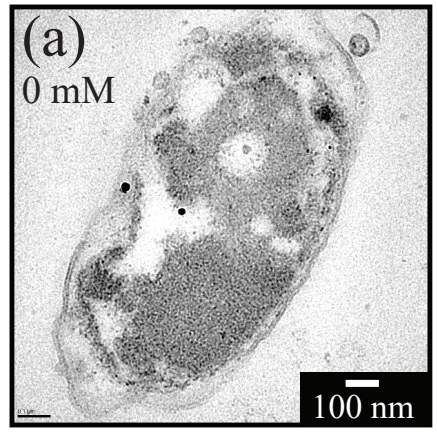

1.9 particles/cell

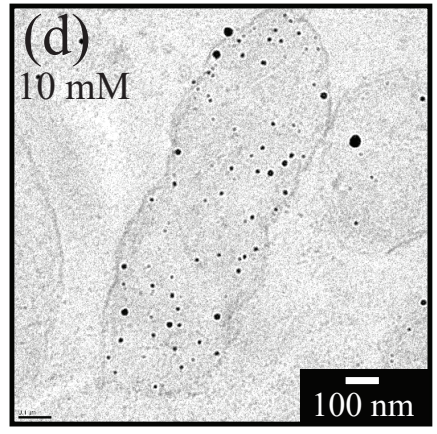

62 particles/cell

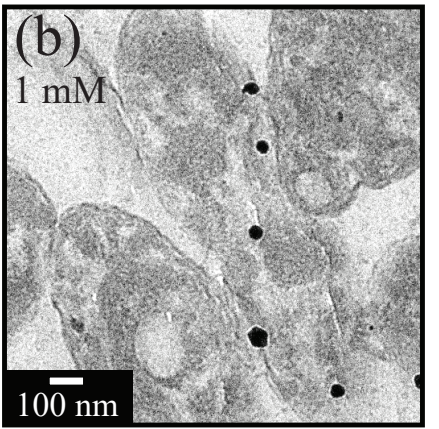

2.3 particles/cell

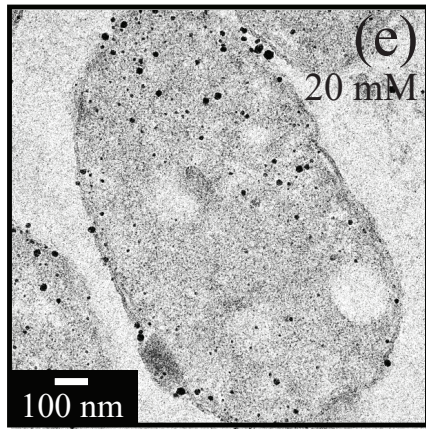

97 particles/cell

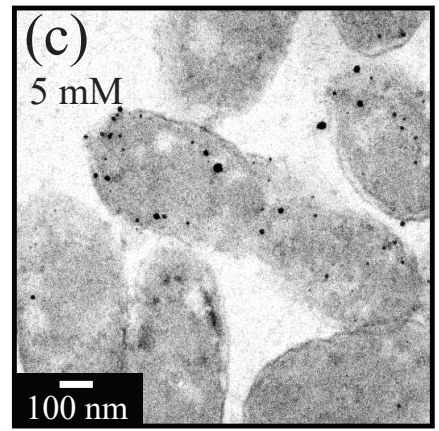

17 particles/cell

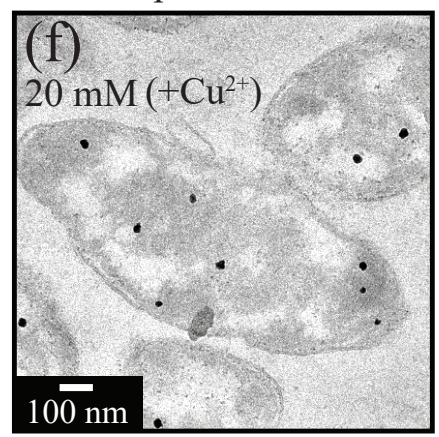

6.5 particles/cell

Figure 5. Ultra-thin section TEM images of Ac. aromatica cells collected at $160 \mathrm{~h}$ after exposure to $10 \mathrm{mg} / \mathrm{L}$ $\mathrm{Au}(\mathrm{III})$. Formate was added as e-donor at; (a) $0 \mathrm{mM}$, (b) $1 \mathrm{mM}$, (c) $5 \mathrm{mM}$, (d) $10 \mathrm{mM}$, or (e) $20 \mathrm{mM}$. (f) As a possible enzymatic inhibitor, $5 \mathrm{mM} \mathrm{Cu}^{2+}$ was simultaneously added together with $20 \mathrm{mM}$ formate. Densities of $\mathrm{Au}(0)$ bionanoparticles (NPs/cell) were calculated and indicated underneath respective TEM images. The total number of particles counted were as follows: (a) $n=25$ (in 13 cells); (b) $n=18$ (in 8 cells); (c) $n=119$ (in 7 cells); (d) $n=493$ (in 8 cells); (e) $n=681$ (in 7 cells); and, (f) $n=71$ (in 11 cells). 


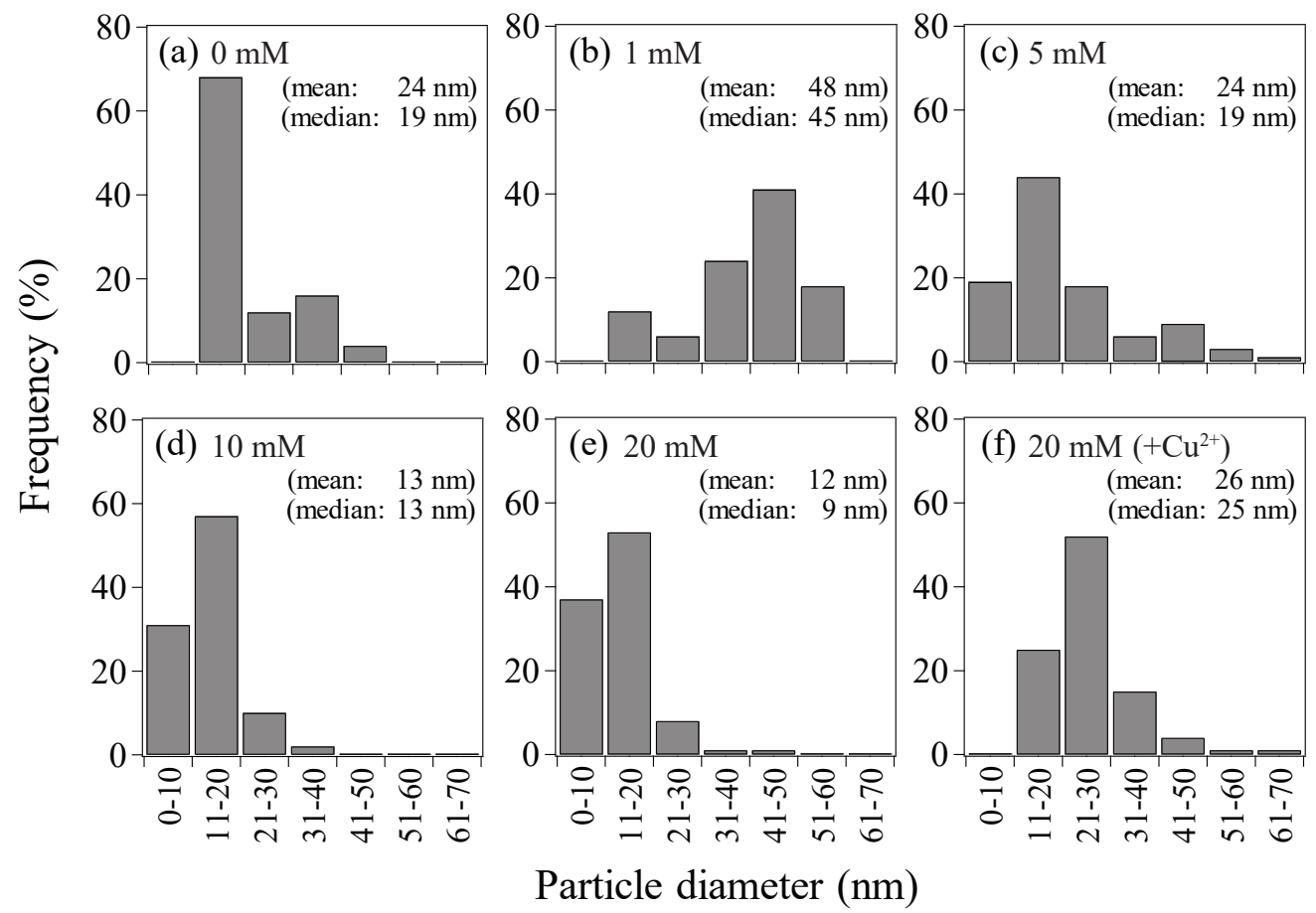

Figure 6. Particle size distribution of $\mathrm{Au}(0)$ bionanoparticles produced by Ac. aromatica at initial formate concentrations of; (a) $0 \mathrm{mM}$ (cf., Figure 5a, $n=25$ ), (b) $1 \mathrm{mM}$ (cf., Figure 5b, $n=18$ ), (c) $5 \mathrm{mM}$ (cf., Figure 5c, $n=119$ ), (d) $10 \mathrm{mM}$ (cf., Figure 5d, $n=493$ ), (e) $20 \mathrm{mM}$ (cf., Figure 5e, $n=681$ ) or (f) $20 \mathrm{mM}+\mathrm{Cu}^{2+}$ (cf., Figure $5 \mathrm{f}, n=71$ ).

\subsubsection{Localization}

According to TEM images, bio-AuNPs were formed intracellularly (both in the periplasmic space and inside cytoplasm; Figure $5 \mathrm{a}-\mathrm{f})$. In the case of $\mathrm{Pd}(0)$ bionanoparticles (bio-PdNPs) production by Ac. aromatica, addition of $\mathrm{Cu}^{2+}$ strongly inhibited initial enzymatic $\mathrm{Pd}(0)$ nucleation, forming only a few, much larger triangle and penta-/hexagonal $\mathrm{Pd}(0)$ particles [13]. Since a similar observation was found with bio-AuNPs formation (as described in Section 3.2.1), it may be possible that a common mechanism is shared between $\operatorname{Pd}(0)$ and $\mathrm{Au}(0)$ bionanoparticles formation by Ac. aromatica and that addition of $\mathrm{Cu}^{2+}$ deactivates most of its responsible enzymatic, as well as "metal trafficking", protein activities.

\subsection{Schematic Summary of Bio-AuNPs Production by Ac. aromatica}

Based on the results obtained above, the schematic flow of bio-AuNPs formation by Ac. aromatica is proposed as shown in Figure 7.

In some studies, the use of $\mathrm{H}_{2}$ (but not organic acids such as lactate) was essential to support $\mathrm{Au}(\mathrm{III})$ reduction $[25,26]$, and the involvement of hydrogenase(s) was suggested in S. algae [25], E. coli and D. desulfuricans [24]. In this study, formate played a role as an effective e-donor. Here, sodium formate (HCOONa) added to cell-suspensions as e-donor exists mostly in the form of formic acid $(\mathrm{HCOOH} ; \mathrm{pKa}=3.8)$ under acidic $\mathrm{pHs}(\mathrm{pH} 2.5$ in this study). Formic acid can diffuse through the cell membrane to deprotonate to cause acidification of the cytoplasm (Equation (1)) [37]. Since the presence of putative formate dehydrogenase (FDH) enzyme is predicted from the genome sequence of Acidocella sp. (e.g., Ac. aminolytica DSM 11237; Acidocella sp. MX-AZ02) [13], formic acid diffused into the cytoplasm can be decomposed by FDH to release $\mathrm{H}_{2}$ gas (Equation (2)) to act as a reducing agent for $\mathrm{Au}(0)$ nucleation.

$$
\begin{gathered}
\mathrm{HCOOH} \rightleftharpoons \mathrm{HCOO}^{-}+\mathrm{H}^{+} \\
\mathrm{HCOOH} \rightarrow \mathrm{CO}_{2}+\mathrm{H}_{2}
\end{gathered}
$$


When formate decomposition (Equation (2)) is chemically facilitated (e.g., by catalytic activity of $\operatorname{Pd}(0) ;[38])$, the resultant $\mathrm{H}_{2}$ gas can readily act as a chemical reducing agent both in extracellular and intracellular (by diffusion through the cell membrane) regions: In fact, when Ac. aromatica was tested for bio-PdNPs production, the addition of a smaller amount of formate (i.e., $5 \mathrm{mM}$ ) was sufficient to reduce $100 \mathrm{mg} / \mathrm{L} \mathrm{Pd(II)} \mathrm{to} \mathrm{produce} \mathrm{finer,} \mathrm{intracellular,} \mathrm{and} \mathrm{periplasmic} \mathrm{bio-PdNPs,} \mathrm{whereas} \mathrm{increasing}$ the formate concentration led to the formation of extracellular $\operatorname{Pd}(0)$ aggregates [13]. This effect was also likely further facilitated by the self-catalytic activity of $\mathrm{H}_{2}$-absorbing $\operatorname{Pd}(0)$.

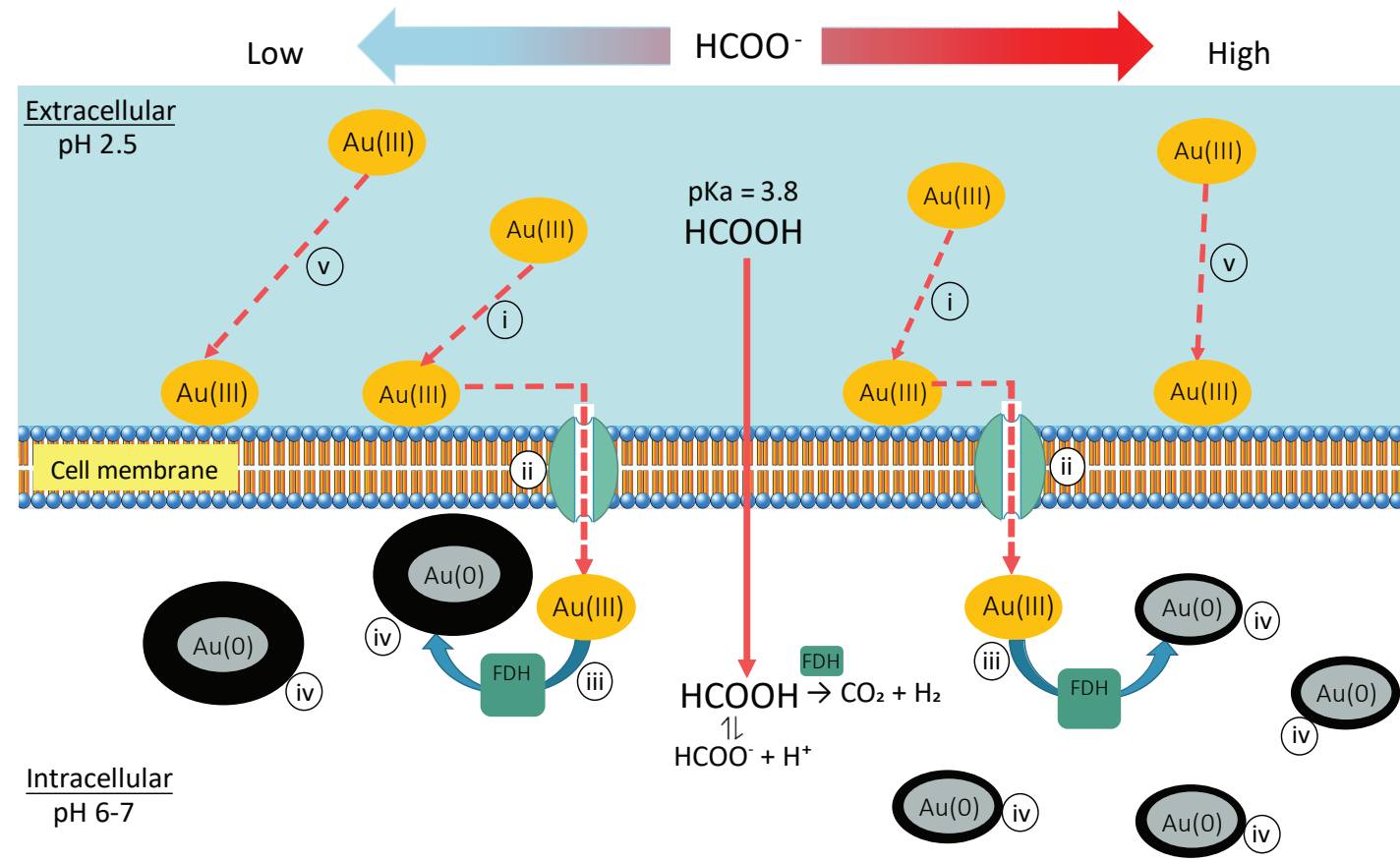

Figure 7. Proposed mechanism of bio-AuNPs production by Ac. aromatica: (i) Au(III) ions (in the form of $\mathrm{AuCl}_{4}{ }^{-}$) are adsorbed onto the slightly positively charged cell surface. (ii) $\mathrm{Au}(\mathrm{III})$ ions are transported into cytoplasm via membrane "Au(III) trafficking" proteins. (iii) $\mathrm{Au}(\mathrm{III})$ ions are reduced to form $\mathrm{Au}(0)$ nuclei via intracellular enzymatic reaction (possibly FDH) to decompose formate to produce $\mathrm{H}_{2}$ as a reducing force (iv) At lower formate concentrations fewer $\mathrm{Au}(0)$ nucleation sites appear leading to greater crystal growth for individual particles, whereas at higher formate concentrations the number of $\mathrm{Au}(0)$ nuclei is increased leading to smaller crystal growth for individual particles. (v) As the flow from (i) to (iv) proceeds, remaining $\mathrm{Au}(\mathrm{III})$ ions left in the bulk solution can sequentially adsorb on the cell surface by occupying a vacancy created upon trafficking of the former adsorbate into the cytoplasm, to further proceed to (ii).

In the case of $\mathrm{Au}$, on contrary to that of Pd [13], addition of an increasing amount of formate corresponded to formation of finer, intracellular and periplasmic bio-AuNPs with a higher density. This was likely because formate decomposition to produce $\mathrm{H}_{2}$ as reducing force mainly occurred as intracellular enzymatic reaction (supposedly FDH) (Figure 7). Accordingly, the use of a greater amount of formate led to the activation of more enzymatic reaction sites (i.e., occurrence of more $\mathrm{Au}(0)$ nucleation loci), and thus a faster Au(III) bioreduction speed (Figure 1). Formation of fewer number of $\mathrm{Au}(0)$ nuclei at lower formate concentrations generally led to greater crystal growth (Figures 4, 6 and 7).

In most of the previous studies, no external e-donor was added to facilitate Au reduction, in other words, the reaction relied on intracellular electron carriers (such as NADH) accumulated during pre-growth (so as the case with $0 \mathrm{mM}$ formate addition in this study). Only a few studies used external e-donors, such as $\mathrm{H}_{2}$ [24-26] and lactate [28]. In any case, the size-control of bio-AuNPs by means of external e-donor had not yet been evaluated in detail. Thus, the results obtained here first 
demonstrated the possibility of size-controlled bacterial bio-AuNPs production by manipulating the e-donor concentration, combined with the use of an enzyme inhibitor.

\section{Conclusions}

- The acidophilic Fe(III)-reducing heterotrophic bacterium, Acidocella aromatica PFBC was successfully used for intracellular gold recovery as bio-AuNPs from highly acidic $\mathrm{Au}(\mathrm{III})$ solutions via a simple one-step reaction.

- Use of increasing concentration of formate (as e-donor) corresponded to a greater number of $\mathrm{Au}(0)$ nucleation sites with less crystal growth: At 1, 5, 10, or $20 \mathrm{mM}$ formate, bio-AuNPs of 48, 24, 13, or $12 \mathrm{~nm}$, with $2.3,17,62$, or 97 particles/cell, respectively, were produced.

- The presence of $\mathrm{Cu}^{2+}$ was inhibitory to intracellular enzymatic reaction, resulting in significantly fewer $\mathrm{Au}(0)$ nucleation, but in enhanced crystal growth.

- It was possible to control the size of bio-AuNPs by modifying the e-donor concentration combined with a use of enzyme inhibitor: bio-AuNPs of $48 \mathrm{~nm}, 26 \mathrm{~nm}$, or $13 \mathrm{~nm}$ (nearly within normal distribution) was produced by use of $1 \mathrm{mM}$ formate, $20 \mathrm{mM}$ formate $\left(+\mathrm{Cu}^{2+}\right)$, or $10 \mathrm{mM}$ formate, respectively.

- The knowledge obtained from this fundamental study is expected to be applied to the actual acidic Au leachate from "urban mine" resources such as Au-bearing printed circuit boards (PCBs).

Acknowledgments: This work was supported by a grant from the Japan Society for the Promotion of Science (JSPS Kakenhi JP16H04616). Ac. aromatica $\mathrm{PFBC}^{\mathrm{T}}$ was kindly provided by D. B. Johnson (University of Bangor, Wales, UK).

Author Contributions: Intan Nurul Rizki performed the experiments and prepared the manuscript draft under the supervision of Naoko Okibe.

Conflicts of Interest: The authors declare no conflict of interest.

\section{References}

1. Bernstein, P.L.; Volcker, P.A. The Power of Gold: The History of an Obsession; John Wiley \& Sons: Hoboken, NJ, USA, 2012.

2. Sperling, R.A.; Gil, P.R.; Zhang, F.; Zanella, M.; Parak, W.J. Biological applications of gold nanoparticles. Chem. Soc. Rev. 2008, 37, 1896-1908. [CrossRef] [PubMed]

3. Chen, P.C.; Mwakwari, S.C.; Oyelere, A.K. Gold nanoparticles: From nanomedicine to nanosensing. Nanotechnol. Sci. Appl. 2008, 1, 45. [PubMed]

4. Das, S.K.; Das, A.R.; Guha, A.K. Gold nanoparticles: Microbial synthesis and application in water hygiene management. Langmuir 2009, 25, 8192-8199. [CrossRef] [PubMed]

5. Dahl, J.A.; Maddux, B.L.; Hutchison, J.E. Toward greener nanosynthesis. Chem. Rev. 2007, 107, $2228-2269$. [CrossRef] [PubMed]

6. Herzing, A.A.; Kiely, C.J.; Carley, A.F.; Landon, P.; Hutchings, G.J. Identification of active gold nanoclusters on iron oxide supports for co oxidation. Science 2008, 321, 1331-1335. [CrossRef] [PubMed]

7. Verma, M.L. Nanobiotechnology advances in enzymatic biosensors for the agri-food industry. Environ. Chem. Lett. 2017, 15, 555-560. [CrossRef]

8. Verma, M.L. Enzymatic nanobiosensors in the agricultural and food industry. In Nanoscience in Food and Agriculture 4; Wiley: Hoboken, NJ, USA, 2017; pp. 229-245.

9. Lee, J.-S.; Cho, J.; Lee, C.; Kim, I.; Park, J.; Kim, Y.-M.; Shin, H.; Lee, J.; Caruso, F. Layer-by-layer assembled charge-trap memory devices with adjustable electronic properties. Nat. Nanotechnol. 2007, 2, 790-795. [CrossRef] [PubMed]

10. Zhao, P.; Li, N.; Astruc, D. State of the art in gold nanoparticle synthesis. Coord. Chem. Rev. 2013, 257, $638-665$. [CrossRef]

11. Rai, M.; Yadav, A.; Gade, A. CRC 675-Current trends in phytosynthesis of metal nanoparticles. Crit. Rev. Biotechnol. 2008, 28, 277-284. [CrossRef] [PubMed] 
12. Mohanpuria, P.; Rana, N.K.; Yadav, S.K. Biosynthesis of nanoparticles: Technological concepts and future applications. J. Nanopart. Res. 2008, 10, 507-517. [CrossRef]

13. Okibe, N.; Nakayama, D.; Matsumoto, T. Palladium bionanoparticles production from acidic Pd(II) solutions and spent catalyst leachate using acidophilic Fe(III)-reducing bacteria. Extremophiles 2017, 21, 1091-1100. [CrossRef] [PubMed]

14. Ehrlich, H.L.; Newman, D.K.; Kappler, A. Ehrlich's Geomicrobiology, 6th ed.; CRC Press: Boca Raton, FL, USA, 2015.

15. Korobushkina, E.; Korobushkin, I. The interaction of gold with bacteria and the formation of new gold. Doklady Akademii Nauk SSSR 1986, 287, 978.

16. Southam, G.; Beveridge, T.J. The in vitro formation of placer gold by bacteria. Geochim. Cosmochim. Acta 1994, 58, 4527-4530. [CrossRef]

17. Southam, G.; Beveridge, T.J. The occurrence of sulfur and phosphorus within bacterially derived crystalline and pseudocrystalline octahedral gold formed in vitro. Geochim. Cosmochim. Acta 1996, 60, 4369-4376. [CrossRef]

18. Kalishwaralal, K.; Deepak, V.; Pandian, S.R.K.; Gurunathan, S. Biological synthesis of gold nanocubes from bacillus licheniformis. Bioresour. Technol. 2009, 100, 5356-5358. [CrossRef] [PubMed]

19. Wen, L.; Lin, Z.; Gu, P.; Zhou, J.; Yao, B.; Chen, G.; Fu, J. Extracellular biosynthesis of monodispersed gold nanoparticles by a SAM capping route. J. Nanopart. Res. 2009, 11, 279-288. [CrossRef]

20. Li, Y.; Li, Y.; Li, Q.; Fan, X.; Gao, J.; Luo, Y. Rapid biosynthesis of gold nanoparticles by the extracellular secretion of bacillus niabensis 45: Characterization and antibiofilm activity. J. Chem. 2016, 2016, 7. [CrossRef]

21. Markus, J.; Mathiyalagan, R.; Kim, Y.-J.; Abbai, R.; Singh, P.; Ahn, S.; Perez, Z.E.J.; Hurh, J.; Yang, D.C. Intracellular synthesis of gold nanoparticles with antioxidant activity by probiotic lactobacillus kimchicus DCY51 ${ }^{\mathrm{T}}$ isolated from Korean kimchi. Enzyme Microb. Technol. 2016, 95, 85-93. [CrossRef] [PubMed]

22. Nair, B.; Pradeep, T. Coalescence of nanoclusters and formation of submicron crystallites assisted by lactobacillus strains. Cryst. Growth Des. 2002, 2, 293-298. [CrossRef]

23. Husseiny, M.; El-Aziz, M.A.; Badr, Y.; Mahmoud, M. Biosynthesis of gold nanoparticles using Pseudomonas aeruginosa. Spectrochim. Acta Part A Mol. Biomol. Spectrosc. 2007, 67, 1003-1006. [CrossRef] [PubMed]

24. Deplanche, K.; Macaskie, L. Biorecovery of gold by Escherichia coli and Desulfovibrio desulfuricans. Biotechnol. Bioeng. 2008, 99, 1055-1064. [CrossRef] [PubMed]

25. Kashefi, K.; Tor, J.M.; Nevin, K.P.; Lovley, D.R. Reductive precipitation of gold by dissimilatory Fe(III)-reducing Bacteria and Archaea. Appl. Environ. Microbiol. 2001, 67, 3275-3279. [CrossRef] [PubMed]

26. Konishi, Y.; Tsukiyama, T.; Ohno, K.; Saitoh, N.; Nomura, T.; Nagamine, S. Intracellular recovery of gold by microbial reduction of $\mathrm{AuCl}_{4}{ }^{-}$ions using the anaerobic bacterium Shewanella algae. Hydrometallurgy 2006, 81, 24-29. [CrossRef]

27. He, S.; Guo, Z.; Zhang, Y.; Zhang, S.; Wang, J.; Gu, N. Biosynthesis of gold nanoparticles using the bacteria Rhodopseudomonas capsulata. Mater. Lett. 2007, 61, 3984-3987. [CrossRef]

28. Feng, Y.; Lin, X.; Wang, Y.; Wang, Y.; Hua, J. Diversity of aurum bioreduction by Rhodobacter capsulatus. Mater. Lett. 2008, 62, 4299-4302. [CrossRef]

29. Nangia, Y.; Wangoo, N.; Sharma, S.; Wu, J.; Dravid, V.; Shekhawat, G.S.; Suri, C.R. Facile biosynthesis of phosphate capped gold nanoparticles by a bacterial isolate Stenotrophomonas maltophilia. Appl. Phys. Lett. 2009, 94, 233901-1-233901-3. [CrossRef]

30. Reith, F.; Rogers, S.L.; McPhail, D.; Webb, D. Biomineralization of gold: Biofilms on bacterioform gold. Science 2006, 313, 233-236. [CrossRef] [PubMed]

31. Lengke, M.; Southam, G. Bioaccumulation of gold by sulfate-reducing bacteria cultured in the presence of gold(I)-thiosulfate complex. Geochim. Cosmochim. Acta 2006, 70, 3646-3661. [CrossRef]

32. Li, J.; Li, Q.; Ma, X.; Tian, B.; Li, T.; Yu, J.; Dai, S.; Weng, Y.; Hua, Y. Biosynthesis of gold nanoparticles by the extreme bacterium Deinococcus radiodurans and an evaluation of their antibacterial properties. Int. J. Nanomed. 2016, 11, 5931-5944. [CrossRef] [PubMed]

33. Lengke, M.F.; Southam, G. The effect of thiosulfate-oxidizing bacteria on the stability of the gold-thiosulfate complex. Geochim. Cosmochim. Acta 2005, 69, 3759-3772. [CrossRef]

34. Jones, R.M.; Hedrich, S.; Johnson, D.B. Acidocella aromatica sp. nov.: An acidophilic heterotrophic alphaproteobacterium with unusual phenotypic traits. Extremophiles 2013, 17, 841-850. [CrossRef] [PubMed]

35. Liz-Marzán, L.M. Nanometals: Formation and color. Mater. Today 2004, 7, 26-31. [CrossRef] 
36. Mulvaney, P. Surface plasmon spectroscopy of nanosized metal particles. Langmuir 1996, 12, $788-800$. [CrossRef]

37. Baker-Austin, C.; Dopson, M. Life in acid: pH homeostasis in acidophiles. Trends Microbiol. 2007, 15, $165-171$. [CrossRef] [PubMed]

38. Hill, S.P.; Winterbottom, J.M. The conversion of polysaccharides to hydrogen gas. Part 1: The palladium catalysed decomposition of formic acid/sodium formate solutions. J. Technol. Biotechnol. 1988, 41, 121-133. [CrossRef]

(c)

(C) 2018 by the authors. Licensee MDPI, Basel, Switzerland. This article is an open access article distributed under the terms and conditions of the Creative Commons Attribution (CC BY) license (http://creativecommons.org/licenses/by/4.0/). 